\title{
Gridded 5-arcmin, simultaneously farm-size- and crop-specific harvested area for 56 countries
}

10 Han $\mathrm{Su}^{1,2}$, Bárbara Willaarts ${ }^{2}$, Diana Luna-Gonzalez ${ }^{2}$, Maarten S. Krol ${ }^{1}$, Rick J. Hogeboom ${ }^{1,3}$

${ }^{1}$ Multidisciplinary Water Management group, Faculty of Engineering Technology, University of Twente, Enschede, 7500AE, the Netherlands

${ }^{2}$ Water Security group, International Institute for Applied Systems Analysis (IIASA), Laxenburg, 2361, Austria

$15{ }^{3}$ Water Footprint Network, Enschede, 7522NB, the Netherlands

Correspondence to: Han Su (h.su@utwente.nl) 
https://doi.org/10.5194/essd-2022-72

Preprint. Discussion started: 7 March 2022

(c) Author(s) 2022. CC BY 4.0 License.

(c) (1)

\section{Abstract.}

20 Farms are not homogeneous. Smaller farms generally have different planted crops, yields, agricultural input, and irrigations compared to larger farms. Mapping farm size could facilitate studies to quantify how water availability and climate change affect small and large farms respectively. Given the lack of gridded farm-size specific data, this study aims to develop a global gridded simultaneously farm-size- and crop-specific dataset of harvested area. We achieved it by downscaling a best-available dataset, which collected direct measurements on crop and farm size, using crop maps, cropland extent, and dominant field size

25 distributions for 2010. Uncertainties in crop maps were explicitly considered by using two crop maps separately during downscaling. Due to data availability, our downscaled maps cover 56 countries accounting for half of the global cropland. Based on the two different crop maps, we have one 5-arcmin gridded, simultaneously farm-size- and crop-specific dataset of harvested area for 11 farm sizes, 27 crops, and 2 farming systems and the other one for 11 farm sizes, 42 crops, and 4 farming systems. The downscaled maps show major planted crops and irrigation change along with farm sizes which support previous

30 findings. Validations show well consistencies with observations on farm-size specific oil palm from satellite images, farm-size specific irrigation from household surveys, and previous studies that map farm size but are not crop-specific. We observed some uncertainties at the grid cell level and found conclusions at the country-level are robust to these uncertainties including the uncertainties from the crop maps. Our downscaled maps will help to explicitly include farm size into global agriculture modeling. The source data, code, and downscaled maps are open-access and free available at 35 https://doi.org/10.5281/zenodo.5747616 (Su et al., 2022). 
https://doi.org/10.5194/essd-2022-72

Preprint. Discussion started: 7 March 2022

(c) Author(s) 2022. CC BY 4.0 License.

\section{Introduction}

There are over 608 million farms around the world (Lowder et al., 2016; Lowder et al., 2021). Land and water resources are not equally distributed among these farms. More than $80 \%$ of these farms are smaller than 2 hectares and they only utilize around 20\% of farmland area (Lowder et al., 2021; Bosc et al., 2013). The largest one percent of farms utilize $70 \%$ of global farmland area (Lowder et al., 2021). Smaller farms also limitedly apply irrigation to adapt to water scarcity in low- and middleincome countries (Ricciardi et al., 2020).

In addition to water and land resources, the characteristics of agricultural production are generally different across farm sizes, which may be country-dependent. For example, in terms of crops, smaller farms plant more fruits, pulses, and roots and tubers while larger farms plant more vegetables, nuts, and oilcrops (Ricciardi et al., 2018b; Herrero et al., 2017). In terms of the use of agricultural practices to increase agricultural productivity, famers that operate smaller farms tend to increase the use of nonfixed inputs, such as fertilizers and pesticides, while larger farms tend to increase fixed inputs, such as machinery (Ren et al., 2019). Smaller farms also have a greater biodiversity on average (Ricciardi et al., 2021; Noack et al., 2021). Though whether smaller farms have a higher yield has undergone a long debate, yield often correlate with farm size (see Rudra (1968);

50 Savastano and Scandizzo (2017); Gollin (2019); Ricciardi et al. (2021)).

These above-mentioned characteristics stimulate studies to explicitly discern small and large scale farms in agriculture studies and map farm sizes (Meyfroidt, 2017; Riesgo et al., 2016). At the global level, mapping farm sizes can be traced back to Lowder et al. (2016), Samberg et al. (2016), and Fritz et al. (2015). Lowder et al. (2016) estimated the country-level distribution of farm size based on multiple agricultural censuses. Samberg et al. (2016) used the Mean Agricultural Area (MAA) to assign each subnational administrative unit with a farm size. This may overestimate the area of small farms because not all farms are small even in the administrative unit dominated by small farms (Ricciardi et al., 2018b). Fritz et al. (2015) developed a gridded global dominant field size map using manually labeled field size data on the satellite images and spatial interpolation. The dominant field size map was updated by Lesiv et al. (2019). When interpreting fields as farms, the small farm area will also be overestimated as large farms can inclue small-sized fields. Herrero et al. (2017) used the country level farm size data from

60 Lowder et al. (2016) and Fritz et al. (2015) to develop a dominant farm size map which was later updated by Mehrabi et al. (2020) using the field size map from Lesiv et al. (2019). Given that dominant farm size only assigns one farm size to each cell (usually $10 \mathrm{~km}$ by $10 \mathrm{~km}$ ), dominant farm size may over/underestimate some kind of farm sizes when it is used to estimate the number of distribution of farm sizes.

Previous studies' efforts on mapping farm size are not crop-specific. One way to estimate the planted crops for different farm

65 sizes is to overlap the farm size map with crop maps, e.g., Monfreda et al. (2008) in Samberg et al. (2016) and Mehrabi et al. (2020), Ray et al. (2013) in Herrero et al. (2017). Due to differences between farm size and MAA, field sizes, and dominant farm sizes and due to possible structural differences in crop choices between farm sizes, overlays with crop maps may lead to biases in the allocation of crop-specific cropping areas to farm sizes (Ricciardi et al., 2018b). 
https://doi.org/10.5194/essd-2022-72

Preprint. Discussion started: 7 March 2022

(c) Author(s) 2022. CC BY 4.0 License.

(c) (i)

To avoid such biases, one way is to develop a simultaneously farm-size- and crop-specific map. Ricciardi et al. (2018b);

70 Ricciardi et al. (2018a) established an empirical global database using agriculture census and household survey that directly measure crop production or area in combination with farm size. This dataset covers half of the global cropland, including data for 56 countries $^{1}$ - with subnational data for 46 countries. Ricciardi's dataset, however, does not have gridded maps, so it has limited capacities to fulfill the need of global climate change and water resources studies where the hydrological model and climate models commonly use grided maps as input. Lacking gridded farm-size- and crop-specific maps limits the evaluations

75 on how water scarcity and climate change affect small and large farms respectively.

This study aims to develop a global gridded, simultaneously farm-size- and crop-specific dataset of harvested areas with additional information on farming systems. Considering the data availability, the baseline year is 2010 with data covering 56 countries. We compiled multiple datasets including cropland extent, field size distribution, and crop distribution and farming systems, and used them to downscale the empirical farm-size- and crop-specific datasets developed by Ricciardi et al. (2018b);

80 Ricciardi et al. (2018a) from the level of administrative units into a 5 arcmin grid cell level. We also explicitly considered the uncertainties in crop distributions by using two crop maps. The resulting downscaled maps were validated with empirical data and compared with previous studies.

\section{Methods}

\subsection{Overview}

85 Imagine that we know the crop area of small and large farms within an administrative unit, to downscale it, if we get a high spatial resolution map of crop area, we may have some idea on where the small and large farms may locate because some crops are planted more by small farms and some crop are planted more by large farms. In addition, if we get the field size distribution within the administrative unit, we have more ideas on where the small and large farms may locate because large fields only belong to large farms and small farms could only locate in small fields. When we combine the information from crop map and field size distribution, even though we could not precisely locate small and large farms, we could estimation their distributions in this administrative unit with some extent of uncertainties. This is how we develop the gridded, simultaneously farm-size- and crop-specific dataset of harvested areas. Theoretically, we could estimate multiple distributions of small and large farms that are consistent with all the administrative level and grid cell level data. Practically, however, these distributions may not exist because of the background inconsistencies among datasets. To deal with the background inconsistencies, we assume the best estimation of the farm-size- and crop-specific distributions are the distributions that could maximize consistencies with datasets. In any cases, we tries to find multiple distributions that meet the same level of consistency with datasets and averaged the multiple distributions to get the final estimation.

1 In their paper, they claim to have data for 55 countries. In the dataset they published, it contains the 56th country, the Czech Republic. 


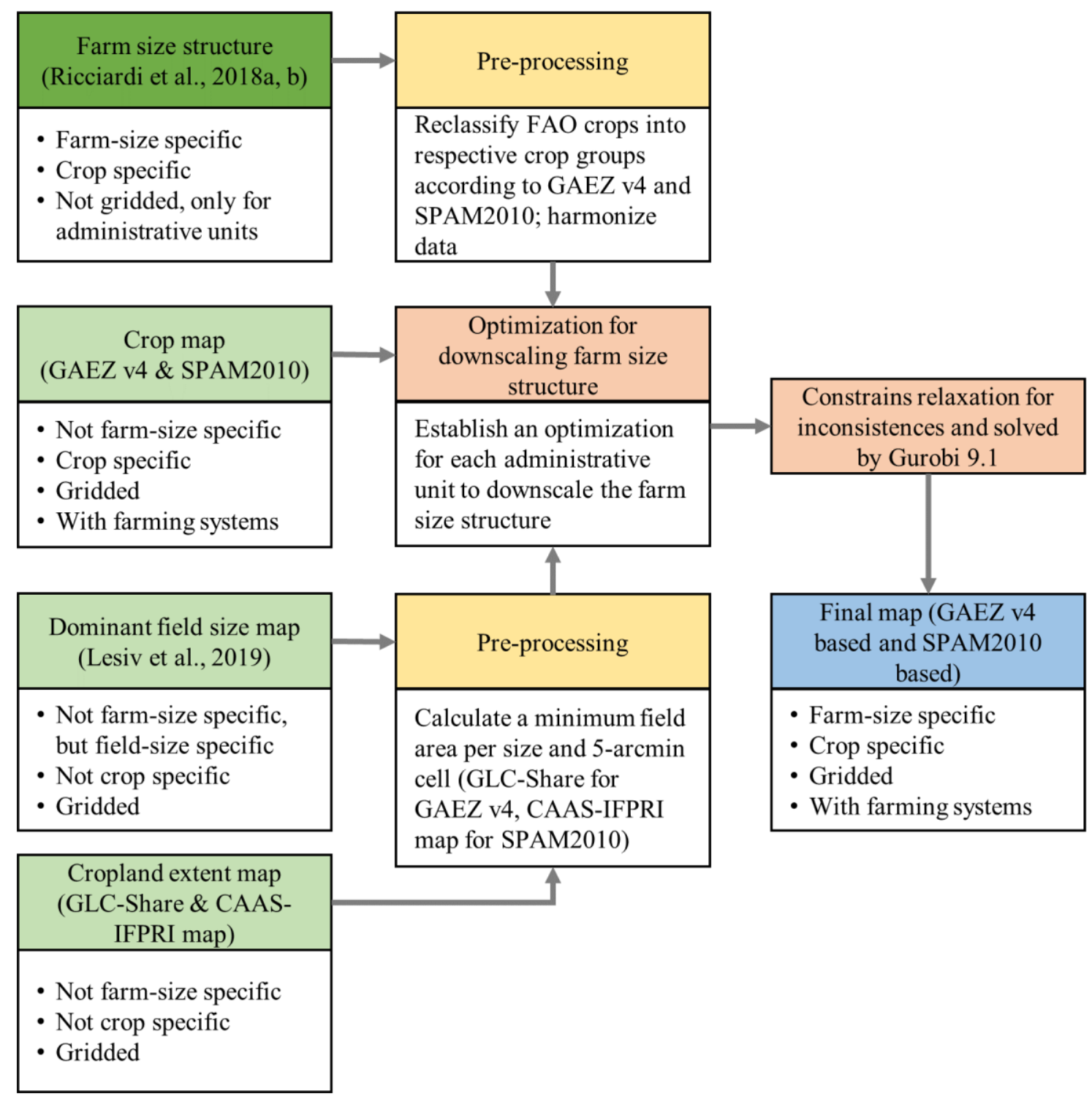

Figure 1. Diagram of map development processors.

100 The map development involved pre-processing of multiple datasets, establishing optimization for downscaling, and constraints relaxation and solving optimization problems (Fig. 1). The pre-processing included two parts: reclassifying crops to accommodate differences in crop classification used in the underlying datasets and harmonizing Ricciardi's dataset, and converting the dominant field size map into a minimum field area per size and 5-arcmin grid cell (Sect. 2.2). The downscaling was achieved by maximizing consistencies with multiple datasets that provide information on the location of each farm size and planted crops. Specifically, we established an optimization for each administrative unit (Sect. 2.3) and solved it via constraints relaxations (Sect. 2.4). Priorities in achieving consistency with the various underlying datasets were considered 
https://doi.org/10.5194/essd-2022-72

Preprint. Discussion started: 7 March 2022

(C) Author(s) 2022. CC BY 4.0 License.

during these processes (Sect. 2.3 and 2.4). The spatial crop distribution affects both crop location and farm size location during downscaling and is usually uncertain. To consider the uncertainties in crop maps, we used two crop maps to develop two alternative versions of the final downscaled map separately.

\subsection{Datasets and pre-processing}

All the datasets used in this study can be found in Table 1. Ricciardi's dataset provides the farm-size- and crop-specific cropping area for 56 countries at the administrative unit level. The eleven farm sizes in this dataset are based on the classification from the World Census of Agriculture (WCA) (Fao, 2020; Ricciardi et al., 2018a): 0-1 ha, 1-2 ha, 2-5 ha, 5-10 ha, 10-20 ha, 20-50 ha, 50-100 ha, 100-200 ha, 200-500 ha, 500-1000 ha, and >1000 ha. The cropping area in this dataset

115 means either crop area, planted area, harvested area, or cultivated area. Because the data quality varies from country to country and this dataset was not harmonized for time, we chose to downscale its crop-specific farm size structure, i.e. the crop-specific percentage of area per farm size, instead of the area. The crop-specific harvested area is from two crop maps separately: GAEZ v4 (Fischer et al., 2021) and SPAM2010 (Yu et al., 2020). They are the only two crop maps containing harvested area of tens crops for the year 2010 at 5 arcmin spatial resolution (Kim et al., 2021). GAEZ v4 and SPAM2010 and have their own crop 120 classification systems ([S1, S2] for details). GAEZ v4 distinguishes two farming systems: irrigated and rainfed. SPAM2010 further distinguishes rainfed into low- and high-input rainfed and subsistence rainfed. The dominant field size distribution (Lesiv et al., 2019) indicates where larger farms may locate. It provides spatial distribution for five field sizes: < 0.64 ha, $0.64-$ 2.56 ha, 2.56-16 ha, 16-100 ha, and >100 ha. For pre-processing, cropland extent maps were also included.

Table 1. Datasets that were used to develop the gridded, farm-size specific, and crop-specific dataset of harvested area.

\begin{tabular}{|c|c|c|c|c|c|}
\hline Dataset & Indicator & Spatial coverage and resolution & Time & Crop & Note \\
\hline $\begin{array}{l}\text { Ricciardi et al. } \\
\text { (2018b); Ricciardi } \\
\text { et al. (2018a) }\end{array}$ & $\begin{array}{l}\text { Farm size } \\
\text { structure* }\end{array}$ & $\begin{array}{l}56 \text { countries; (sub)national } \\
\text { administrative unit }\end{array}$ & $\begin{array}{l}\text { Varies from } \\
2001 \text { to } 2015\end{array}$ & $\begin{array}{l}154 \text { FAO } \\
\text { crops }\end{array}$ & 11 farm sizes \\
\hline $\begin{array}{l}\text { GAEZ v4 (Fischer } \\
\text { et al., 2021) }\end{array}$ & $\begin{array}{l}\text { Harvested } \\
\text { area }\end{array}$ & Global; gridded, 5 arcmin & 2010 & $\begin{array}{l}27 \text { GAEZ } \\
\text { crops** }\end{array}$ & $\begin{array}{l}2 \text { farming systems } \\
\text { (irrigated and rainfed) }\end{array}$ \\
\hline $\begin{array}{l}\text { SPAM2010 (Yu et } \\
\text { al., 2020) }\end{array}$ & $\begin{array}{l}\text { Harvested } \\
\text { area }\end{array}$ & Global; gridded, 5 arcmin & 2010 & $\begin{array}{l}42 \text { SPAM } \\
\text { crops }\end{array}$ & $\begin{array}{l}4 \text { farming systems } \\
\text { (irrigated, low- and } \\
\text { high-input rainfed and } \\
\text { subsistence rainfed) }\end{array}$ \\
\hline $\begin{array}{l}\text { Dominant field } \\
\text { size distribution } \\
\text { (Lesiv et al., 2019) }\end{array}$ & $\begin{array}{l}\text { Dominant } \\
\text { field size }\end{array}$ & Global; gridded, $1 \mathrm{~km}$ & $\begin{array}{l}\text { Varies from } \\
2000 \text { to } 2017\end{array}$ & $\begin{array}{l}\text { Not crop- } \\
\text { specific }\end{array}$ & 5 field sizes \\
\hline
\end{tabular}


https://doi.org/10.5194/essd-2022-72

Preprint. Discussion started: 7 March 2022

(c) Author(s) 2022. CC BY 4.0 License.

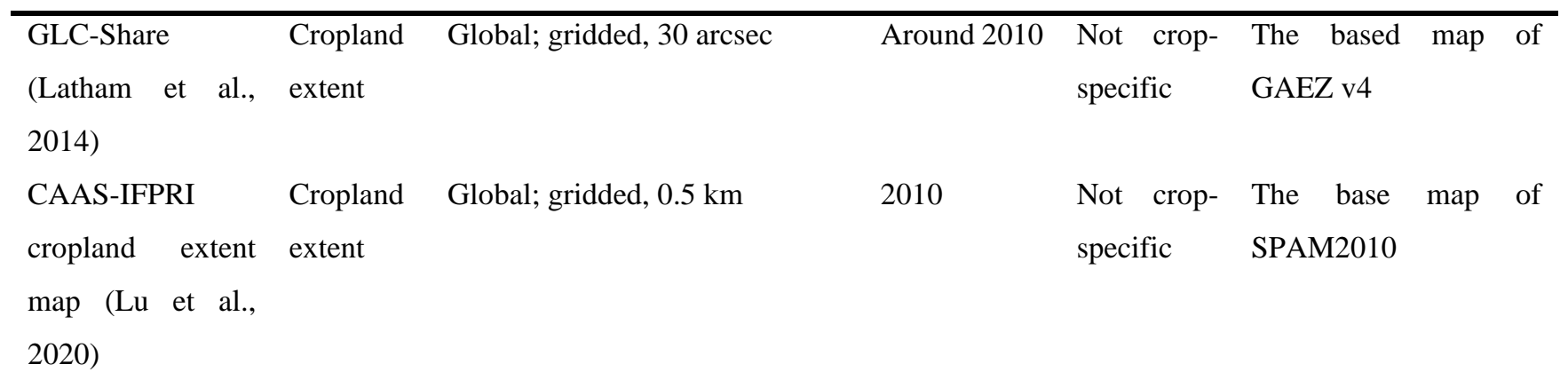

* Here we mean the crop-specific percentage of harvested area per farm size within an administrative unit

** The 27th crop is Fruits and Nuts which is not listed in the document but available in their dataset

To pre-process Ricciardi's dataset, we first reclassified the FAO crops in this dataset into 27 GAEZ crops and 42 SPAM crops respectively. Detailed criteria can be found in [S1, S2]. We used the cropping area to get the crop-specific farm size structure. In this dataset, the cropping area includes four items: crop area, planted area, harvested area, and cultivated area. One or two

130 items are available for most countries. To harmonize data, when more than one item is available, we used the item with a larger overall area (after crop reclassification) to estimate farm size structure because larger overall area means more farm size classes have available data in most cases. If neither of the four items is available, we used crop production data provided by Ricciardi's dataset to get the crop-specific farm size structure. In this case, we assumed constant yield across farm sizes.

We also converted the $1 * 1 \mathrm{~km}$ dominant field size map into a minimum field area per size and 5-arcmin cell during pre-

135 processing. We interpreted dominant field size as a field of that size account for at least $50 \%$ of cropland at the cell. For each field size, we calculated the minimum field area by using the $50 \%$ of cropland extent that is dominated by the respective field size. We then summed and scaled the minimum field area to cover all croplands of 5-arcmin cells. To keep cropland extent consistent with crop map during downscaling, GLC-Share is used when crop map is GAEZ v4; CAAS-IFPRI cropland extent map is used when crop map is SPAM2010. The minimum field area of size 16-100 ha is 120 ha in the cell \#23 means, for

140 example, farms larger than 16 ha should occupy at least 120 ha in the cell \#23.

\subsection{Optimization for downscaling}

For each administrative unit defined in Ricciardi's dataset, we established the following optimization problem for downscaling:

\section{Sets:}

$c$, Crops

$145 f$, Farm size, labelled by the lower bound of the eleven farm sizes

$e$, Field size, labelled by the lower bound of the five field sizes

$s$, Farming system

$a$, Administrative unit

$g$, Grid cell 
150 Parameters:

ha. $R_{c, f, a}$, Crop-specific farm size structure, percentage of the harvested area of farm size $f$ that plant crop $c$ in the administrative unit $a$, from Ricciardi's dataset

ha. $S_{c, s, g}$, Harvested area of crop $c$ under farming system $s$ at grid cell $g$, from crop map

ha. $L_{e, g}$, Minimum field area of field size $e$ at grid cell $g$, from dominant field size map and crop extent map

$155 p_{f}$, The minimum farm area of farm size $f$ in any gird cell when the farm size $f$ exist; it is the lower bound of the farm size class $f$

$l$, Elastic factor

Variables:

$h a_{c, f, s, g}$ Harvested area of crop $c$, farm size $f$, farming system $s$ at grid cell $g$, estimated by this study

\section{Objective function:}

Since we aim to downscale Ricciardi's dataset, we wanted to maximize consistencies with Ricciardi's dataset when constraints allow:

$$
\min \sum_{c, f} a b s\left(h a \cdot R_{c, f, a} \sum_{s, g \in a} h a \cdot S_{c, s, g}-\sum_{s, g \in a} h a_{c, f, s, g}\right)
$$

\section{Constraints:}

The first constraint ensures consistencies with crop map: the total harvested per crop per farming system per grid cell in our map equals the harvested area per crop per farming system per grid cell in the crop map.

$$
\sum_{f} h a_{c, f, s, g}=h a \cdot S_{c, s, g}, \forall c, s, g
$$

The second constraint ensures minimum consistencies with Ricciardi's dataset. The relative difference in farm size structure between our estimation and Ricciardi's dataset would be less than 10\%. This ensures that we do not diverge far from Ricciardi's dataset when other constraints are hard to meet. In this case, we would relax other constraints to ensure these minimum consistencies with Ricciardi's dataset. The arbitrary 10\% relative difference considers timestamp differences in Ricciardi's dataset and overall uncertainties underlying each of the datasets.

$$
90 \% * h a . R_{c, f, a} \sum_{s, g \in a} h a . S_{c, s, g} \leq \sum_{s, g \in a} h a_{c, f, s, g} \leq 110 \% * h a \cdot R_{c, f, a} \sum_{s, g \in a} h a \cdot S_{c, s, g}, \forall c, f
$$

Thirdly, we also applied a minimum allocated area for each farm size at each grid cell. Since the farm size is defined based on the total operated or cultivated area that does not need to be a single crop area and single farming system, this constraint is not necessarily required by the definition of farm size. It is still reasonable to include it because we applied it at the 5 -arcmin $(\sim 10$ $\mathrm{km})$ grid cell level. Considering the uncertainties in these constraints and inconsistencies among datasets, we consider this constraint in a hard form and soft form. We used hard form by default. We consider relaxing these constraints using the soft 
form when the optimization is infeasible (see Sect. 2.4). The soft form does not require the minimum allocation area for each farming system.

Hard form

$$
h a_{c, f, s, g} \geq p_{f}, \forall c, f, s, g, \text { if } h a_{c, f, s, g}>0
$$

Soft form

$$
\sum_{s} h a_{c, f, s, g} \geq l \times p_{f}, \forall c, f, g, \text { if } h a_{c, f, s, g}>0
$$

180 Fourthly, we applied a minimum area constraint for some farm sizes according to the dominant field size distribution. This constraint follows the logic that a field could only belong to an equal or larger size of farm. We assumed a linear distribution of area within each farm size to accommodate the different classifications of size in farms and fields.

Given the area of field larger than 100 ha, for farms larger than 100 ha:

$$
\sum_{c, s, f \geq 100} h a_{c, f, s, g} \geq h a . L_{100, g}, \forall g
$$

Given the area of field larger than 16 ha, for farms larger than 10 ha:

$$
\sum_{c, s, f \geq 20} h a_{c, f, s, g}+\frac{20-16}{20-10} \sum_{c, s} h a_{c, 10, s, g} \geq h a . L_{100, g}+h a \cdot L_{16, g}, \forall g
$$

185 Given the area of field larger than 2.56 ha, for farms larger than 2 ha:

$$
\sum_{c, s, f \geq 5} h a_{c, f, s, g}+\frac{5-2.56}{5-2} \sum_{c, s} h a_{c, 2, s, g} \geq h a . L_{100, g}+h a . L_{16, g}+h a \cdot L_{2.56, g}, \forall g
$$

Given the area of field larger than 0.64 ha, for all farms:

$$
\sum_{c, s, f \geq 1} h a_{c, f, s, g}+\frac{1-0.64}{1-0} \sum_{c, s} h a_{c, 0, s, g} \geq h a . L_{100, g}+h a \cdot L_{16, g}+h a \cdot L_{2.56, g}+h a \cdot L_{0.64, g}, \forall g
$$

Last but not least, we have non-negative area constraints:

$$
h a_{c, f, s, g} \geq 0, \forall c, f, s, g
$$

\subsection{Constraints relaxation and solving procedures}

When the above optimization (Eq. (1)-(10)) is infeasible due to the inconsistencies among datasets, we first replaced the hard form of minimum allocated area for each farm size (Eq. (4)) with soft form (Eq. (5)) and tried the elastic factor with following values by order: $1,1 / 2,1 / 4,1 / 8,1 / 16,1 / 32,1 / 64$, and 0 . If it is still infeasible, we relaxed the minimum area constraint required by the dominant field size distribution by removing the constraints from large to small farms until the optimization is feasible. Relaxing the minimum area constraint does not happen often during downscaling.

Whenever the above optimization becomes feasible, the optimization does not necessarily yield a unique global optimum. We calculated up to 80 (sub)optimal solutions with the same level of consistencies and averaged these solutions to get the final 
https://doi.org/10.5194/essd-2022-72

Preprint. Discussion started: 7 March 2022

(c) Author(s) 2022. CC BY 4.0 License.

(c) (i)

one. This helps us to avoid potential bias of single optimal solutions. There may be still bias on the final averaged solution because the number and quality of solutions depend on the searching process of solving the toolbox.

Each optimization problem was solved by Gurobi v9.1 using the dual simplex method with a time limit of 150 seconds. Gurobi v9.1 is a fast commercial optimization solver (Gurobi Optimization, 2021). Most of the optimization problems in this study could be solved within 60 seconds with the optimal solutions. For the administrative units containing more than 3005 -arcmin grid cells, the optimization problem becomes extremely large posing a great challenge for the solver. The number of decision variables would be more than half-million. In this case, we applied a two-tiered optimization. We first randomly divided all grid cells into several groups. Each group includes around 100 grid cells (for Russia, it was 200 to keep the number of groups below 300). We first solved the optimization problem at the group level. Then, we solved the cell-level optimization for each group. Of 3421 administrative units, 244 units need to be dealt with in this way - they cover $89.4 \%$ of grid cells in this study. The whole computation was performed on a desktop computer (Intel(R) Core(TM) i7-8700 CPU @ 3.20GHz, RAM 16 GB) taking 9 days.

Finally, we masked the farm size of crops as unknown if these crops are not covered by Ricciardi's dataset. For these crops, the optimization could estimate their farm size components, but the uncertainties are significantly larger than those covered by Ricciardi's dataset.

\subsection{Validation of downscaled maps and comparison with previous studies mapping farm sizes}

The ideal way to validate our downscaled simultaneously farm-size- and crop-specific dataset is to compare with observations. However, most of the available datasets are not farm-size specific. This puts challenges to validating our downscaled maps for all crops and farming systems. We searched for validation datasets that are global focused, farm-size specific with additional information on crop or farming systems. Limited by data availability, we were able to validate our downscaled maps with two empirical datasets and we compared with previous studies to access the reliability of our downscaled maps. More validations are expected when more validation datasets are available.

For the first validation with empirical datasets, we compared our downscaled map with Descals et al. (2020) on oil palm production. Descals et al. (2020) developed a global gridded farm-size specific oil palm map using deep learning and satellite images for 2019 (Fig. A1). With satellite images, they classified oil palm areas into small-scale farms and large-scale farms based on landscape features. In order to interpret this size classification, we adopted the definition of small-scale oil palm farms by Indonesia (the world's largest palm oil producer and exporter) and used 25 ha as the threshold for the two scales (Descals et al., 2020). Due to the coverage of our datasets, the validation was in five countries (Fig. A1). The crop Oil palm in GAEZ v4 and SPAM2010 based map was used for validation separately. We calculated the Pearson correlation coefficient between our downscaled map and Descals et al. (2020) at grid cell level on three spatial scales using spatial moving average, 5 arcmin, 15 arcmin, and 25 arcmin.

For the second validation with empirical datasets, we compared our downscaled maps with farm-size specific irrigation at the country level using the FAO RuLIS (Rural Livelihoods Information System) database (Fao, 2021). Eleven of 56 countries' 
https://doi.org/10.5194/essd-2022-72

Preprint. Discussion started: 7 March 2022

(c) Author(s) 2022. CC BY 4.0 License.

(c) (i)

micro-level household survey data around 2010 are available [S3]. Based on the household surveys, we calculated the percentage of the total irrigated area (irrigated area divided by cultivated area) for each farm size (classified by crop area) where at least 5 survey samples are available. We calculated the correlations between our estimations and household surveys. This validation considers farm-size specific farming systems, with data aggregated over crops.

We also compared our downscaled map with previous studies, Lowder et al. (2016) and Mehrabi et al. (2020), which mapped the geographic distribution of farm sizes but were not crop-specific and not farm-system specific. Lowder et al. (2016) provides the percentage of harvested area operated by each farm size at the country level. Mehrabi's dataset keeps the same farm size distribution as Lowder's dataset at the country level but provides the dominant farm size per 5-arcmin grid cell. We got the dominant farm size from our downscaled map with the farm size that operates the largest total harvested area per grid cell for GAEZ based downscaled map and SPAM based downscaled map respectively. The comparison was pixel-to-pixel by counting the number of cells that have similar, larger, and smaller dominant farm size in our maps compared with Mehrabi's dataset.

240 Similar dominant farm size means the farm size in our downscaled map are the same or next to the farm size in Mehrabi's dataset.

\section{Results and analysis}

\subsection{The crop type and farm size}

With the crop map from GAEZ v4 (SPAM2010), we got the 5-arcmin gridded harvested area for 56 countries, 11 farm sizes, 24527 crops (42 crops for SPAM based map), and 2 farming systems (4 farming systems for SPAM based map). Overall, our results show the preference for crop groups for eleven farm sizes ([S1] for the crop group of 27 GAEZ crops). As farm size increases, oil crops and fodder crops become more popular; fruits and nuts, pulses, and roots and tubers become less popular (Fig. 2(a)). Larger farms ( $>20$ ha) dominate the planting of fodder crops, sugar crops and oilcrops; smaller farms $(<20$ ha) dominate the planting of vegetables, stimulates, roots and tubers, pulses, fruits and nuts and cotton (Fig. 2(b)). The SPAM based map shows similar results (Fig. A2 and [S2]). These results are consistent with our datasets Ricciardi et al. (2018b) and previous studies Herrero et al. (2017), which indicate that the optimization resulted in modest remaining inconsistency. 
https://doi.org/10.5194/essd-2022-72

Preprint. Discussion started: 7 March 2022

(C) Author(s) 2022. CC BY 4.0 License.

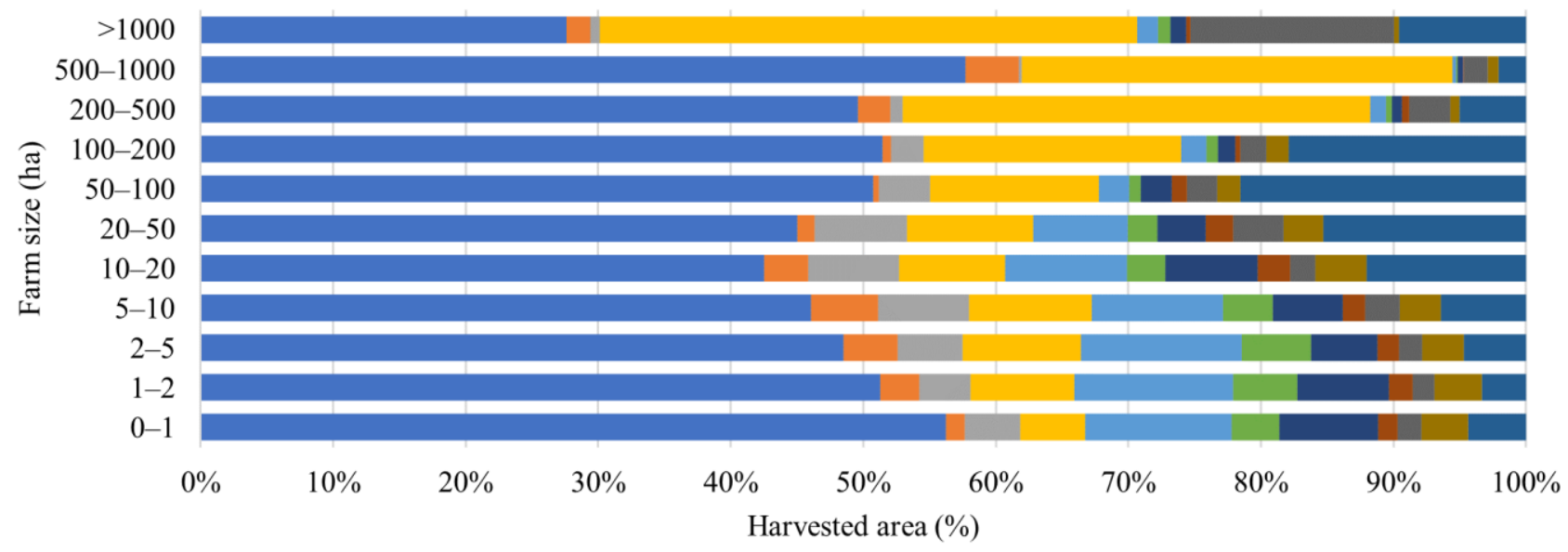

\begin{tabular}{|c|c|c|c|}
\hline - Cereals & Fruits \& nuts & $\varpi$ Oilcrops & — Pulses \\
\hline 口 Roots \& tubers $\square$ Stimulates & - Sugar crops & Vegetables & - Fodder crops \\
\hline
\end{tabular}

(a)

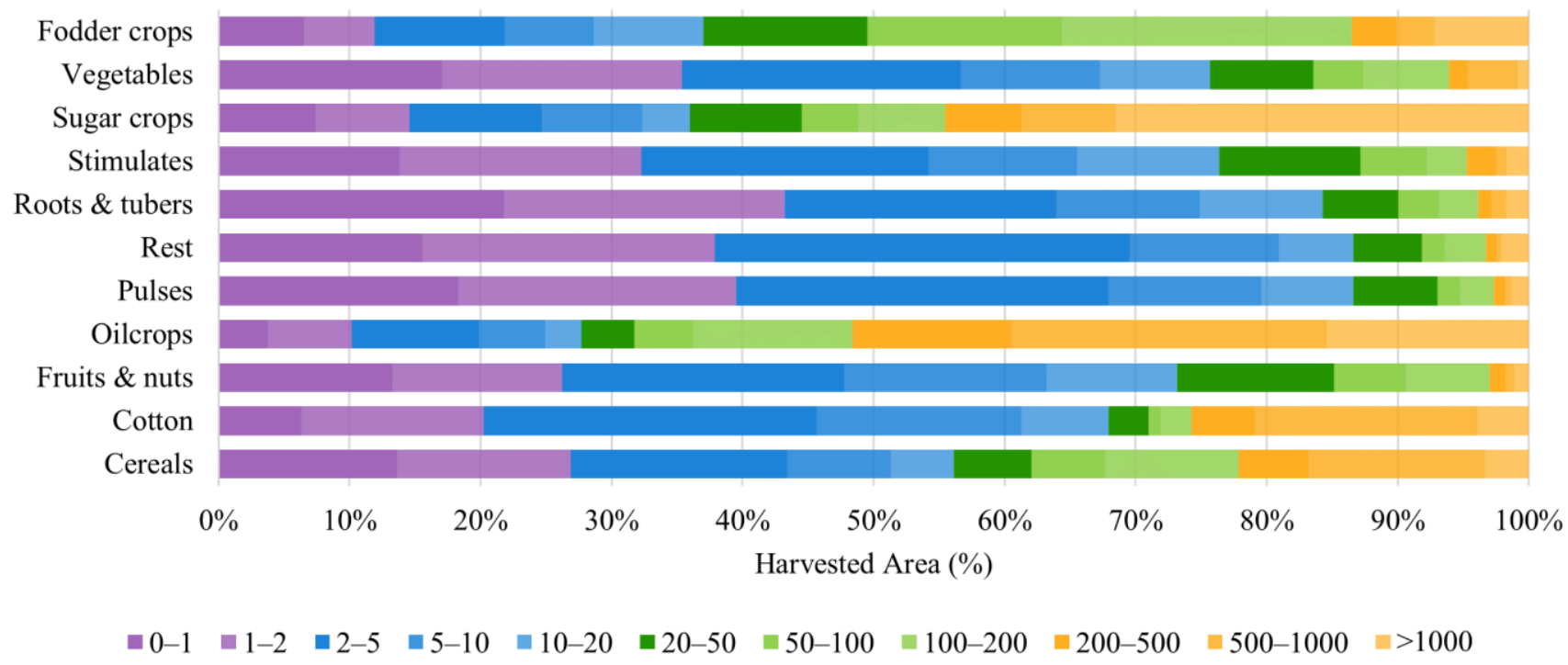

(b)

Figure 2. Harvested area of crop groups within each farm size (a) and harvested area of crop groups by farm size (b) according to GAEZ based downscaled map.

\subsection{Irrigation and farm size}

Overall, our results show that smaller farms irrigate a larger share of their area than larger farms (Fig. 3(a)), which support the findings of Ricciardi et al. (2020). For some countries, it is may not be true (Sect. 3.4 for further details). The overall higher irrigation of smaller farms is due to most of small farms are in the severe water scarce regions (Fig. 3(b)). Here, to get water scarcity information, we overlapped our downscaled map with the blue water scarcity map where water scarcity is classified 
https://doi.org/10.5194/essd-2022-72

Preprint. Discussion started: 7 March 2022

(c) Author(s) 2022. CC BY 4.0 License.

(c) (i)

as four levels: low, moderate, significant, and severe water scarcity (Hoekstra et al., 2012). It remains unknown whether smaller farms adapt to water scarcity via irrigation or irrigation of smaller farms increase water scarcity (Grafton et al., 2018).

With water scarcity, we observed higher irrigation of larger farms when water resources become scarce, which still supports the findings of Ricciardi et al. (2020). The irrigation increases when the level of water scarcity increases. Larger farms irrigate more under moderate, significant, and severe water scarcity (Fig. 3(a)). The same trend can also be found in the SPAM based downscaled map (Fig. A4).

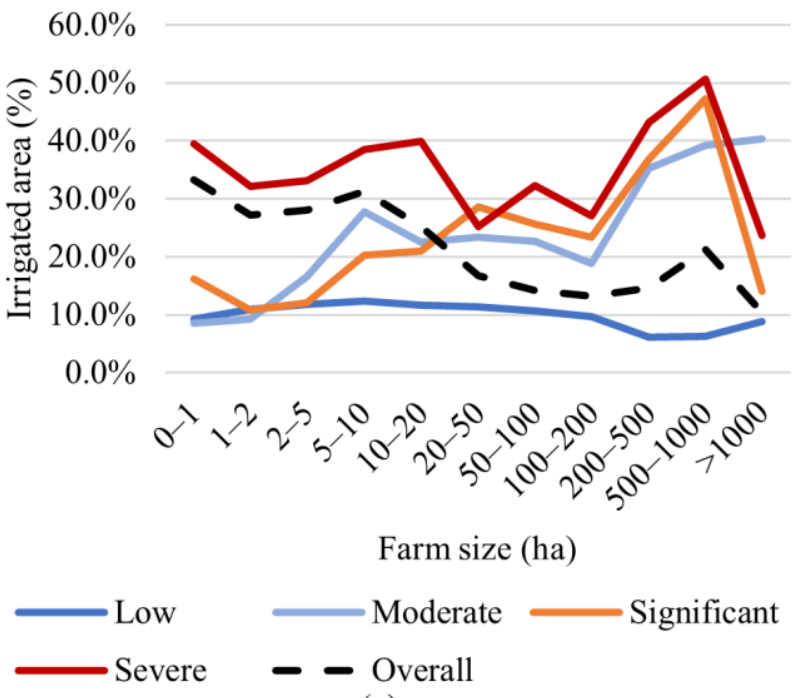

(a)

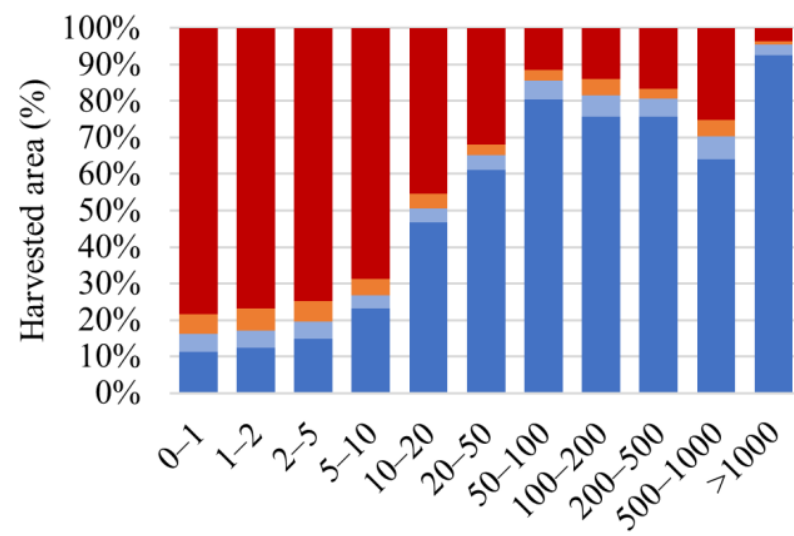

Farm size (ha)

$$
\text { - Low } \square \text { Moderate } \square \text { Significant } \square \text { Severe }
$$

(b)

Figure 3. The percentage of the irrigated area by farm size under each water scarcity level (a) and levels of water scarcity within each farm size (b) according to GAEZ based downscaled map.

\subsection{Validated with farm-size specific oil palm from satellite images}

Validations with farm-size specific oil palm data show a significant positive correlation between our downscaled maps and the validation dataset in most countries for both small-scale and large-scale farms (Table 2). At larger spatial scales, the correlation becomes stronger. This means the spatial distributions of oil palm production in our downscaled maps and Descals et al. (2020) are similar. Still, there are some differences especially in the case of Costa Rica and the United Republic of Tanzania.

Part of the above differences results from the inconsistencies between the crop maps we used and validation dataset. We compared all farms area between crop maps and validation dataset, i.e. the total area of small-scale and large-scale farms (Table 2). We noticed that if the cropland location in crop maps differs from the validation map (not significant positive correlation), the farm-size specific validation will be poor. This means that our estimations are limited by the accuracies of farm location in crop maps. The differences between validations results for the GAEZ based map and the SPAM based map can also be attributed to the same reason, the differences in farm location between GAEZ v4 and SPAM2010. 
https://doi.org/10.5194/essd-2022-72

Preprint. Discussion started: 7 March 2022

(c) Author(s) 2022. CC BY 4.0 License.

(c) (1)

Table 2. Pearson correlation coefficient of the harvested area between oil palms from satellite images Descals et al. (2020) and GAEZ based downscaled map and SPAM based downscaled map respectively for small-scale farms, large-scale farms and all farms. Since all farms results do not distinguish farm size, they indicate the differences in oil palm spatial distribution between Descals et al. (2020) and crop map datasets (GAEZ v4 and SPAM2010).

\begin{tabular}{|c|c|c|c|c|c|c|c|c|c|c|}
\hline & & \multicolumn{3}{|c|}{ Small-scale farms } & \multicolumn{3}{|c|}{ Large-scale farms } & \multicolumn{3}{|c|}{ All farms } \\
\hline & & $5 \operatorname{arcmin}$ & $\begin{array}{c}15 \\
\operatorname{arcmin}\end{array}$ & $\begin{array}{c}25 \\
\operatorname{arcmin}\end{array}$ & $\begin{array}{c}5 \\
\operatorname{arcmin}\end{array}$ & $\begin{array}{c}15 \\
\operatorname{arcmin}\end{array}$ & $\begin{array}{c}25 \\
\operatorname{arcmin}\end{array}$ & $\begin{array}{c}5 \\
\operatorname{arcmin}\end{array}$ & $\begin{array}{c}15 \\
\operatorname{arcmin}\end{array}$ & $\begin{array}{c}25 \\
\operatorname{arcmin}\end{array}$ \\
\hline \multirow[t]{2}{*}{ Colombia } & $\begin{array}{l}\text { GAEZ } \\
\text { based }\end{array}$ & $0.177 *$ & $0.313 * *$ & $0.397 * *$ & $0.112 * *$ & $0.238 * *$ & $0.334 * *$ & $0.232 * *$ & $0.374 * *$ & $0.465 * *$ \\
\hline & $\begin{array}{l}\text { SPAM } \\
\text { based }\end{array}$ & $0.218 * *$ & $0.547 * *$ & $0.684 * *$ & $0.385^{* *}$ & $0.620 * *$ & $0.701 * *$ & $0.409 * *$ & $0.652 * *$ & $0.729 * *$ \\
\hline \multirow[t]{2}{*}{$\begin{array}{l}\text { Costa } \\
\text { Rica }\end{array}$} & $\begin{array}{l}\text { GAEZ } \\
\text { based }\end{array}$ & 0.086 & $0.183 * *$ & $0.215^{* *}$ & -0.012 & -0.074 & $\begin{array}{l}- \\
0.144 * *\end{array}$ & 0.032 & 0.001 & -0.043 \\
\hline & $\begin{array}{l}\text { SPAM } \\
\text { based }\end{array}$ & $0.836 * *$ & $0.944 * *$ & $0.971 * *$ & $0.771 * *$ & $0.891 * *$ & $0.925 * *$ & $0.877 * *$ & $0.925 * *$ & $0.929 * *$ \\
\hline \multirow[t]{2}{*}{ Brazil } & $\begin{array}{l}\text { GAEZ } \\
\text { based }\end{array}$ & $0.245^{* *}$ & $0.396 * *$ & $0.483 * *$ & $0.177 * *$ & $0.258 * *$ & $0.271 * *$ & $0.326 * *$ & $0.398 * *$ & $0.423 * *$ \\
\hline & $\begin{array}{l}\text { SPAM } \\
\text { based }\end{array}$ & $0.133 * *$ & $0.190 * *$ & $0.248 * *$ & $0.087 * *$ & $0.091 * *$ & $0.084 * *$ & $0.148 * *$ & $0.154 * *$ & $0.156 * *$ \\
\hline \multirow{2}{*}{$\begin{array}{l}\text { United } \\
\text { republic } \\
\text { of } \\
\text { Tanzania }\end{array}$} & $\begin{array}{l}\text { GAEZ } \\
\text { based }\end{array}$ & 0.01 & $-0.109 *$ & $\begin{array}{l}- \\
0.202 * *\end{array}$ & -0.011 & -0.039 & -0.063 & 0.022 & $-0.115^{*}$ & $\begin{array}{l}- \\
0.218 * *\end{array}$ \\
\hline & $\begin{array}{l}\text { SPAM } \\
\text { based }\end{array}$ & 0.024 & 0.025 & 0.069 & & & & 0.022 & 0.014 & 0.065 \\
\hline \multirow[t]{2}{*}{ Peru } & $\begin{array}{l}\text { GAEZ } \\
\text { based }\end{array}$ & $0.172 * *$ & $0.350 * *$ & $0.438 * *$ & 0.024 & $0.139 * *$ & $0.237 * *$ & $0.111 * *$ & $0.263 * *$ & $0.363^{* *}$ \\
\hline & $\begin{array}{l}\text { SPAM } \\
\text { based }\end{array}$ & $0.367 * *$ & $0.389 * *$ & $0.429 * *$ & $0.141 * *$ & $0.216 * *$ & $0.240 * *$ & $0.302 * *$ & $0.395 * *$ & $0.436^{* *}$ \\
\hline
\end{tabular}

\subsection{Validated with farm-size specific irrigation from household surveys}

Our results also have positive correlations with household surveys in farm-size specific irrigation for the GAEZ based map (Fig. 4(a)) and the SPAM based map (Fig. 4(b)) respectively. This means that our downscaled maps are consistent with 290 validation data in terms of country-level farm-size specific irrigation. Detailed results show that the maps could capture the higher percentage of irrigated areas in small or large farms in most countries along the indications of household surveys [S4]. 
https://doi.org/10.5194/essd-2022-72

Preprint. Discussion started: 7 March 2022

(c) Author(s) 2022. CC BY 4.0 License.

From the validations, we noticed that our downscaled maps systematically underestimate the extent of the irrigated area compared to household survey, both for the GAEZ based map and the SPAM based map. If we compare the percentages of irrigated area for all farms from the datasets, we find these underestimations are still there (Fig. 4(c), (d)). This means the underestimation may come from the different measurements of irrigated area and cultivated area in the validation dataset and datasets of the crop map.

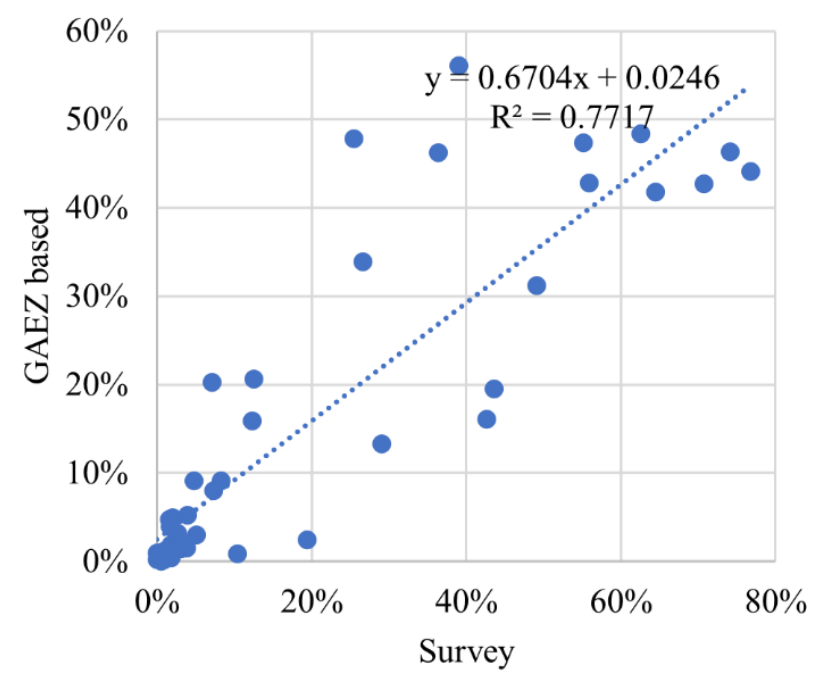

(a)

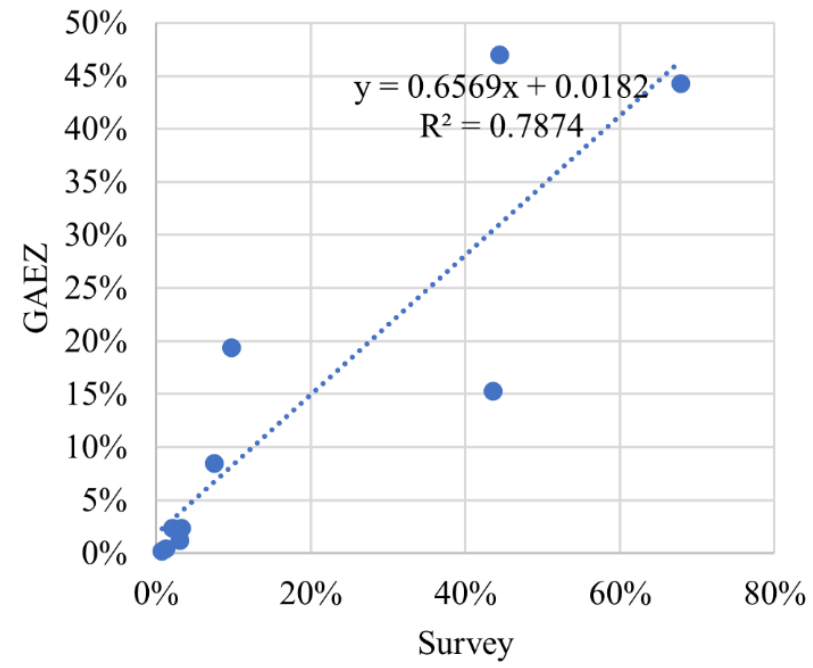

(c)

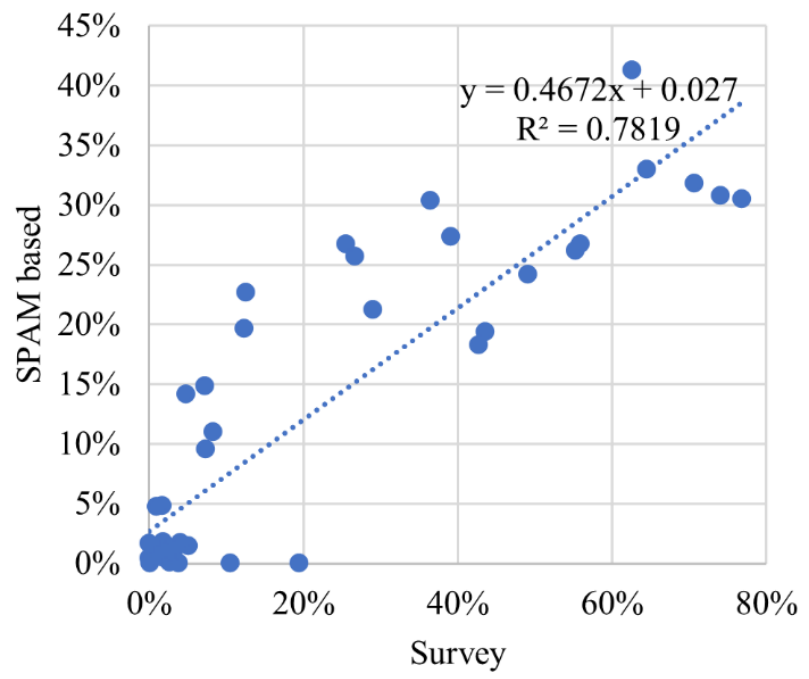

(b)

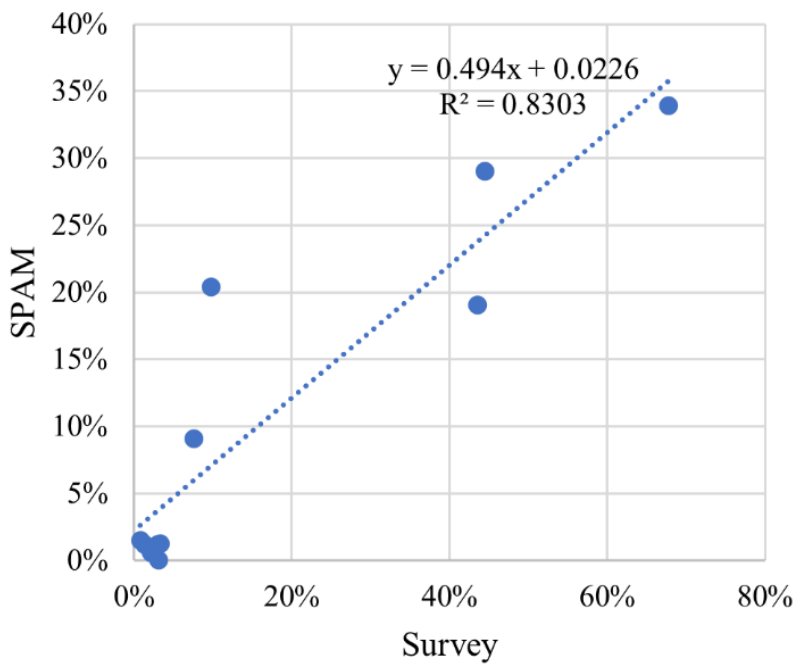

(d)

Figure 4. Correlations on the farm-size specific irrigated area (\% of total harvested area per farm size) between household survey and GAEZ based downscaled map (a) and SPAM based downscaled map (b) for eleven countries. The correlations on the irrigated area of all farms (\% of the total harvested area) between household survey and GAEZ v4 (c) and SPAM2010 (d) are also provided. 
https://doi.org/10.5194/essd-2022-72

Preprint. Discussion started: 7 March 2022

(c) Author(s) 2022. CC BY 4.0 License.

(c) (i)

\subsection{Compared with previous studies mapping farm sizes}

Compared with Lowder's dataset (Lowder et al., 2016), we observed positive correlations for GAEZ based map (Fig. 5(a)) and SPAM based map (Fig. 5(b)). This means at the country level, the amount of farms for each farm size is similar to Lowder's dataset ([S5] for details). There are still differences between our downscaled map and Lowder's dataset. For example, Lowder's dataset estimate $78.5 \%$ of harvested area is under the farm size 50-100 ha in Bulgaria while our downscaled maps give around $5 \%$. However, our downscaled maps estimate around $80 \%$ of harvested are in under the farm size 100-200 ha there while Lowder's dataset gives zero. In this case, our downscaled maps are still similar to Lowder's dataset even though it was not reflected in the correlations. These differences may be attributed to that Lowder's dataset was developed for the year 2000 which is ten years earlier than what we focused. Farm sizes may change during the ten years in some countries.

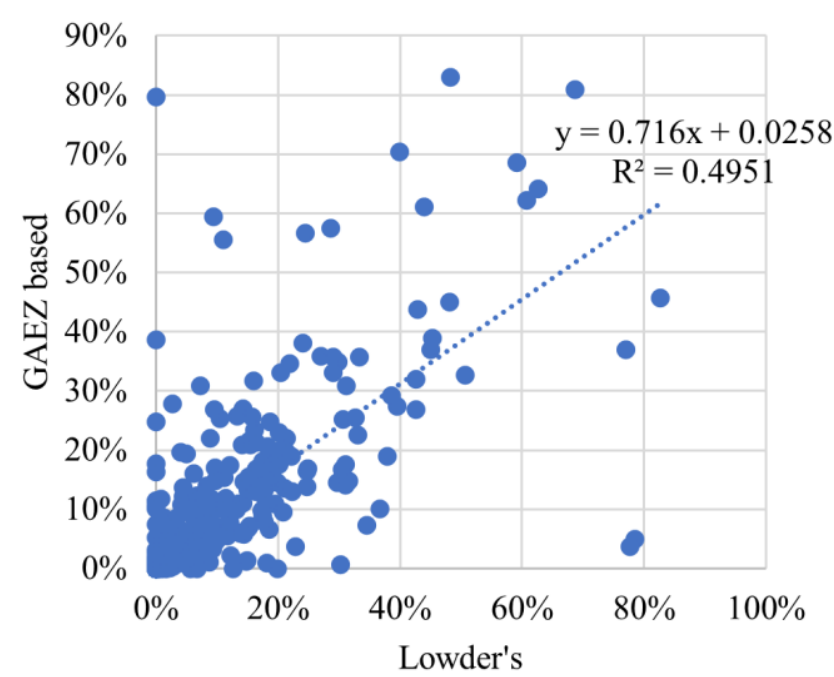

(a)

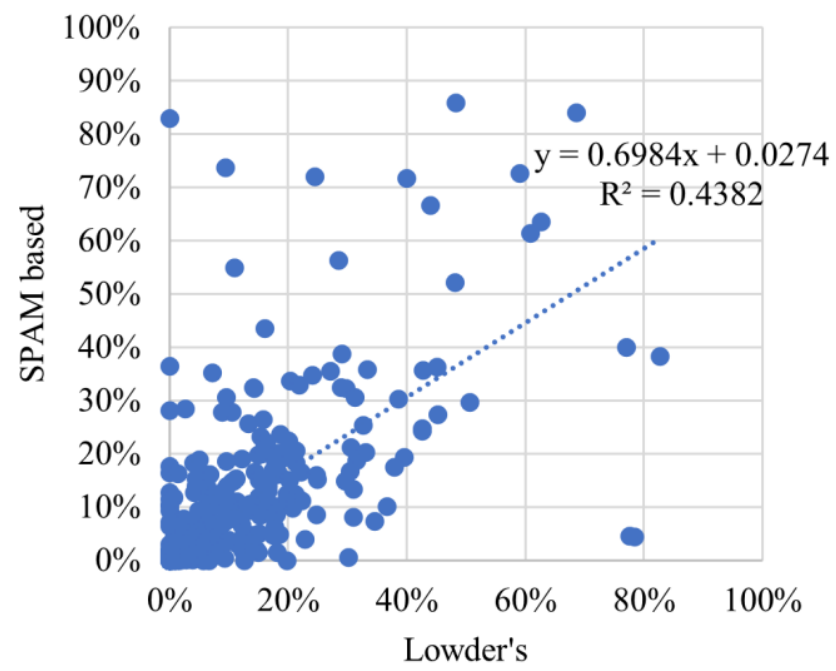

(b)

Figure 5. Correlations on the percentage of harvested area operated by each farm size between Lowder's dataset (Lowder et al., 2016) and GAEZ based downscaled map (a) and SPAM based downscaled map (b) for 37 countries and 11 farm sizes.

Compared with Mehrabi et al. (2020), the same pattern of the spatial distributions of dominant farm size could be observed in the Mehrabi's dataset (Fig. 6(a)), the GAEZ downscaled map (Fig. 6(b)), and SPAM based downscaled map (Fig. 6(c)). Overall, for GAEZ based downscaled map, 54.2\% of grid cells' dominant farm sizes are similar to that in Mehrabi's dataset, $27.5 \%$ are larger, and $18.3 \%$ are smaller; for SPAM based downscaled map, $52.8 \%$ are similar, $26.0 \%$ are larger, and $21.2 \%$ are smaller ([S6] for details). These differences may be partly explained by the above comparison with Lowder's dataset since Mehrabi's dataset has the same country-level farm size distribution as Lowder's dataset. Some differences could also be attributed to the comparison of dominant farm size: the dominant farm size in Mehrabi's dataset may be the second-dominant farm size in our downscaled map. The comparison of dominant farm size may magnify the difference in estimating the overall farm sizes. Since Mehrabi's dataset only include dominant farm size, it is not clear that how the difference would be estimating the overall farm sizes. 
https://doi.org/10.5194/essd-2022-72

Preprint. Discussion started: 7 March 2022

(c) Author(s) 2022. CC BY 4.0 License.

(c) (1)
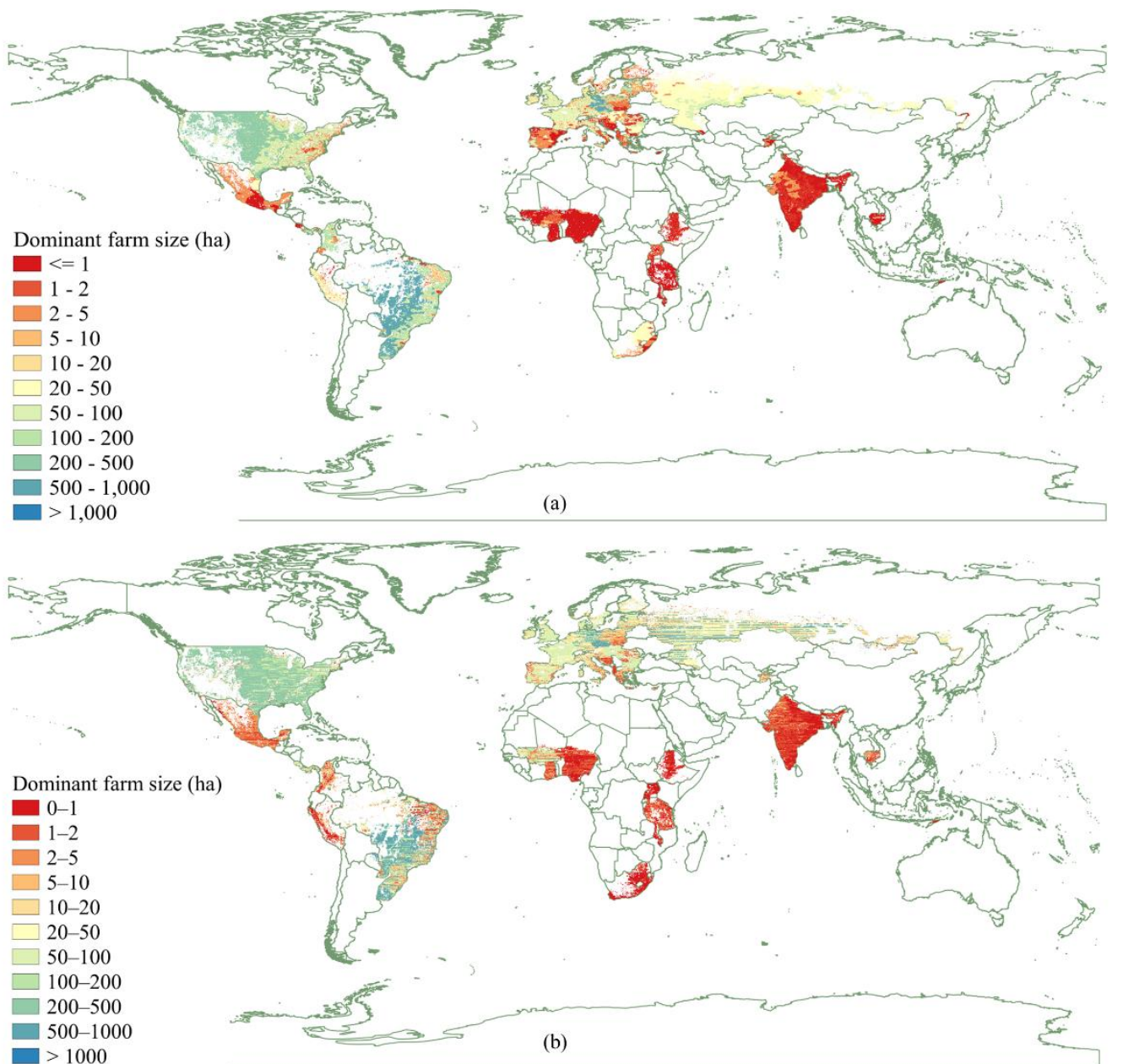

$>1000$

(b)

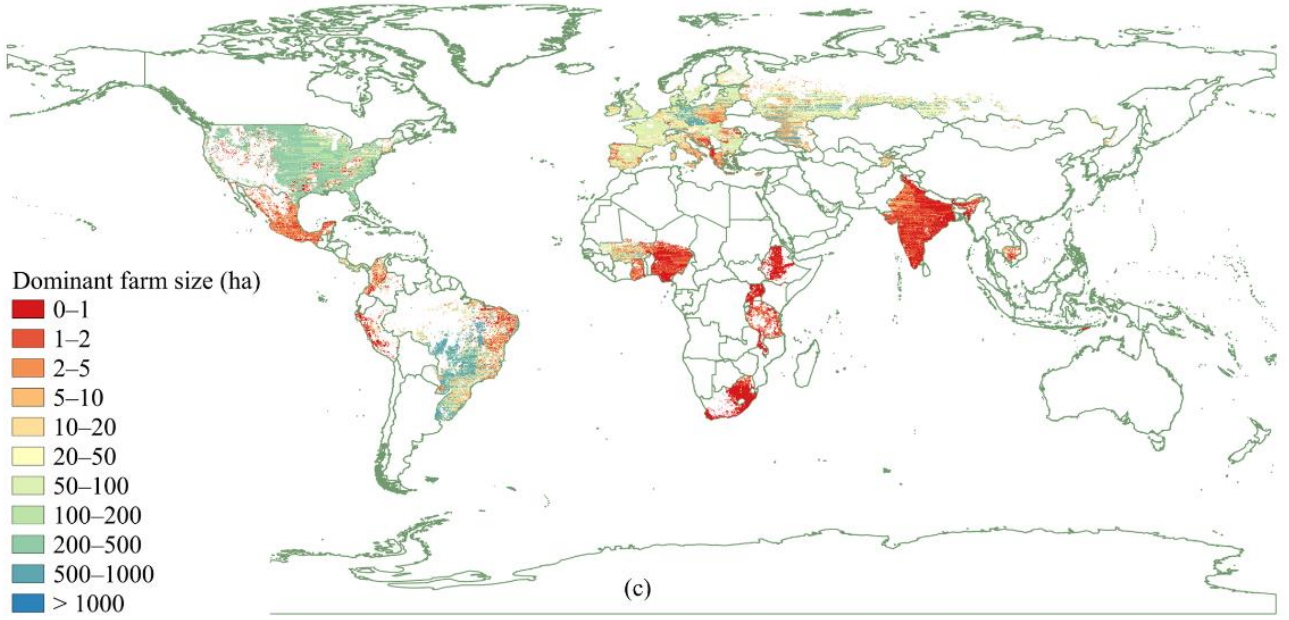

Figure 6. Dominant farm size according to Mehrabi's dataset (Mehrabi et al., 2020) (a), GAEZ based downscaled map (b) and SPAM based downscaled map (c). We only show the cells from Mehrabi's dataset where our downscaled maps have estimations. 
https://doi.org/10.5194/essd-2022-72

Preprint. Discussion started: 7 March 2022

(c) Author(s) 2022. CC BY 4.0 License.

\section{Discussion}

\subsection{Uncertainties}

We explicitly consider the uncertainties in crop maps by developing two separate downscaled maps based on two crop maps, GAEZ v4 and SPAM2010. From the results and validations, we observed some differences in the crop distribution between the two crop maps, especially at the grid cell level. This reflects the uncertainties in farmland location. It affects the spatial validations on farm-size specific oil palm and the dominant farm size distribution. However, these uncertainties at the grid cell level have a limited impact on country level results and validations which can be seen from Fig. 2-Fig. 5, Fig. A2, and Fig. A3.

Uncertainty in the two crop maps is more pronounced for irrigation. From Fig. 4 and [S4] we could see the SPAM based downscaled map has a lower irrigation ratio than GAEZ based downscaled map. This is because SPAM2010 defines irrigation according to the actually irrigated area and GAEZ v4 defines irrigation by the area that is equipped with fully irrigation facilities. The lower irrigation ratio in SPAM2010 does not affect the conclusions and validations drawn from the GAEZ based map; for example, the finding of overall higher irrigation of smaller farms is robust under this uncertainty, and so is the observation on higher irrigation of larger farms under the high level of water scarcity.

340 Some uncertainties are introduced by pre-processing and constraints relaxation during the solving processes. When estimating crop-specific farm size structures using Ricciardi's datasets, around $12 \%$ of them were based on crop production instead of crop area. According to Ricciardi et al. (2018a), the introduced uncertainties are limited when using crop production. In terms of uncertainties introduced by constraints relaxation, for GAEZ (SPAM) based map, we solved 7381 (6017) optimizations. GAEZ v4 and SPAM2010 based downscaling solved different number of optimizations because of the different cropland

345 extent which affect the number of grid cells to be allocated. Among all the optimizations, 4378 (3671) need to be relaxed using elastic factor 0.125 or smaller (Eq. (5)); 239 (203) need to be further relaxed by removing some of the minimum area constraints (Eq. (6) - (9)). Only the relaxation of minimum area constraint will introduce additional inconsistencies with datasets used. This means the constraints relaxation introduce additional uncertainties among $3 \%$ of the total calculations. In addition, we might allocate crop area to a farm size that is not included in Ricciardi's dataset. This only happened when the crop and part of the eleven farm sizes are included in Ricciardi's dataset but meeting the minimum area constraints requires an additional farm size for the crop. In this case, the 10\% relative difference with Ricciardi's dataset is still ensured for the available farm size. Only $0.1 \%(5.0 \%)$ of allocated area is in this case for GAEZ (SPAM) based downscaled map.

More uncertainties in the downscaled maps may come from used datasets. Since Ricciardi's dataset was not developed for 2010, farm size may change a lot in some developing countries. This put some uncertainties in our results since we relied on

355 it to estimate farm size structure. The uncertainties in the crop map affect how we downscaled Ricciardi's dataset. Some crops can be found in Ricciardi's dataset for an administrative unit but not in crop map, or vice versa. This leads to that, on the one hand, $23.3 \%$ (21.6\%) of the crop area in Ricciardi's dataset was not downscaled because the GAEZ v4 (SPAM2010) crop map indicates no crop. On the other hand, $17.8 \%$ (12.4\%) of the harvested area in the GAEZ v4 (SPAM2010) crop map was not 
https://doi.org/10.5194/essd-2022-72

Preprint. Discussion started: 7 March 2022

(c) Author(s) 2022. CC BY 4.0 License.

(c) (i)

allocated a farm size because Ricciardi's dataset has no relevant records. These uncertainties may have affected the allocated

area in the downscaled maps, but according to validations, they are not high enough to make the downscaled maps lose the utilities. High accurate crop map will reduce this part of uncertainties in the future.

Despite the uncertainties at the grid cell level, the used datasets and the downscaled maps were found more reliable at the country level. For example, the two crop maps were developed by downscaling the agriculture census at the (sub)national level. The differences in the two crop maps result from the collected agriculture census and social-ecological factors considered during downscaling. They were all adjusted to the country-level data from FAOSTAT (Fao, 2019). The dominant field size distribution is also uncertain at the grid cell level which was estimated by spatial interpolating of training samples. The uncertainty will decrease when the focus is on the regional level (Lesiv et al., 2019). Validations also show well consistencies with country level observations. Therefore, future uses of our downscaled map are more confident at the country level than grid cell level. Using GAEZ based map and SPAM based map at the same time helps to reduce uncertainties at the grid cell level.

\subsection{Limitations}

With the ambition to map global simultaneously farm-size- and crop-specific harvested area, we were only able to cover 56 countries due to data availability, though it is already half of the global cropland. Farm-size specific data is scarce and sometimes not publicly available in some countries. The datasets we used, like Ricciardi et al. (2018b) and Lesiv et al. (2019), are the currently best-available datasets on farm or field sizes (Kim et al., 2021). Data availability is the main obstacle to get a global map. The development of deep learning and remote sensing may help to map the global farm-size- and crop-specific harvested are in another way, like the farm-size specific oil palm in Descals et al. (2020). Lacking of farm size training samples and enormous computational requirements are the main challenges for deep learning and remote sensing.

Our estimation are based on planted crop and harvested area, which is static for the year 2010. Farmers' choice on crop will change along with climate, market, and so on. Current downscaled maps could only provide a baseline for the distributions of small and large farms. It remains challenging to describe the dynamics of harvested area under changing environment.

The future updates of our downscaled maps rely on the updates of our datasets. Fortunately, GAEZ v4, SPAM2010, and the cropland extent map have regular update plans according to their document. The dominant field size distribution was also updated since the first publishing and may have more updates in the future. Ricciardi's dataset may not have updated plans but it could be updated using the data from World Programme for the Census of Agriculture (Fao, 2020) and EUROSTAT (Eurostat, 2021).

\section{Code and data availability}

The code, source data, and the simultaneously farm-size- and crop-specific harvested area, including the GAEZ based downscaled map and SPAM based downscaled map, are open-access, free, and available at 
https://doi.org/10.5194/essd-2022-72

Preprint. Discussion started: 7 March 2022

(c) Author(s) 2022. CC BY 4.0 License.

(c) (1)

390 https://doi.org/10.5281/zenodo.5747616 (Su et al., 2022). The downscaled maps are available in *.csv files for each crop and farming system. Each *.csv file provides the grid cell index, administrative unit index, crop name, farm size, harvested area, and $\mathrm{x}$ and $\mathrm{y}$ coordinates in the projection of WGS84.

\section{Conclusions}

This study presents a 5-arcmin gridded simultaneously farm-size- and crop-specific dataset of harvested area for 56 countries.

395 We downscaled the best-available datasets, Ricciardi et al. (2018b) which collected direct reports of farm size and crop area, by using the latest datasets on crop-specific land use, cropland extent, and field size distribution. We explicitly addressed the uncertainty in crop maps by using two crop maps separately during downscaling. The downscaled maps are well-consistent with observations on farm-size specific oil palm cultivation from satellite images and farm-size specific irrigation from household surveys. Our downscaled maps show the planted crops and irrigation differ among farm sizes which support 400 previous findings. We observed uncertainties in the maps produced at the grid cell level but found country-level conclusions to be robust to grid cell level uncertainties, including the uncertainties from crop maps.

Intended future updates will increase the spatial coverage. Our simultaneously farm-size- and crop-specific dataset will facilitate studies to explicitly incorporate farm size into global agriculture, water resources, and climate change studies.

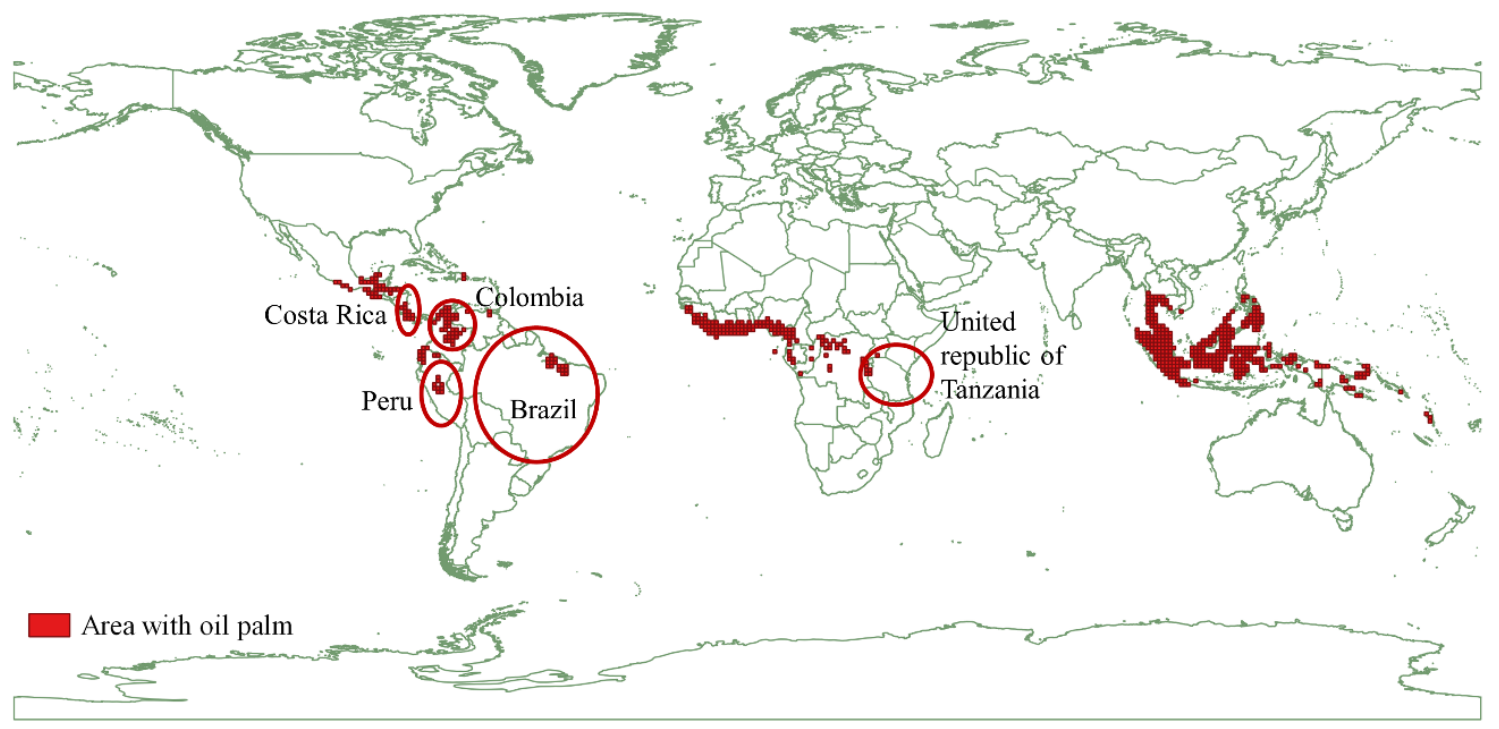

Figure A1. The global distribution of oil palms according to Descals et al. (2020) and the five countries to validate our downscaled maps. 
https://doi.org/10.5194/essd-2022-72

Preprint. Discussion started: 7 March 2022

(c) Author(s) 2022. CC BY 4.0 License.

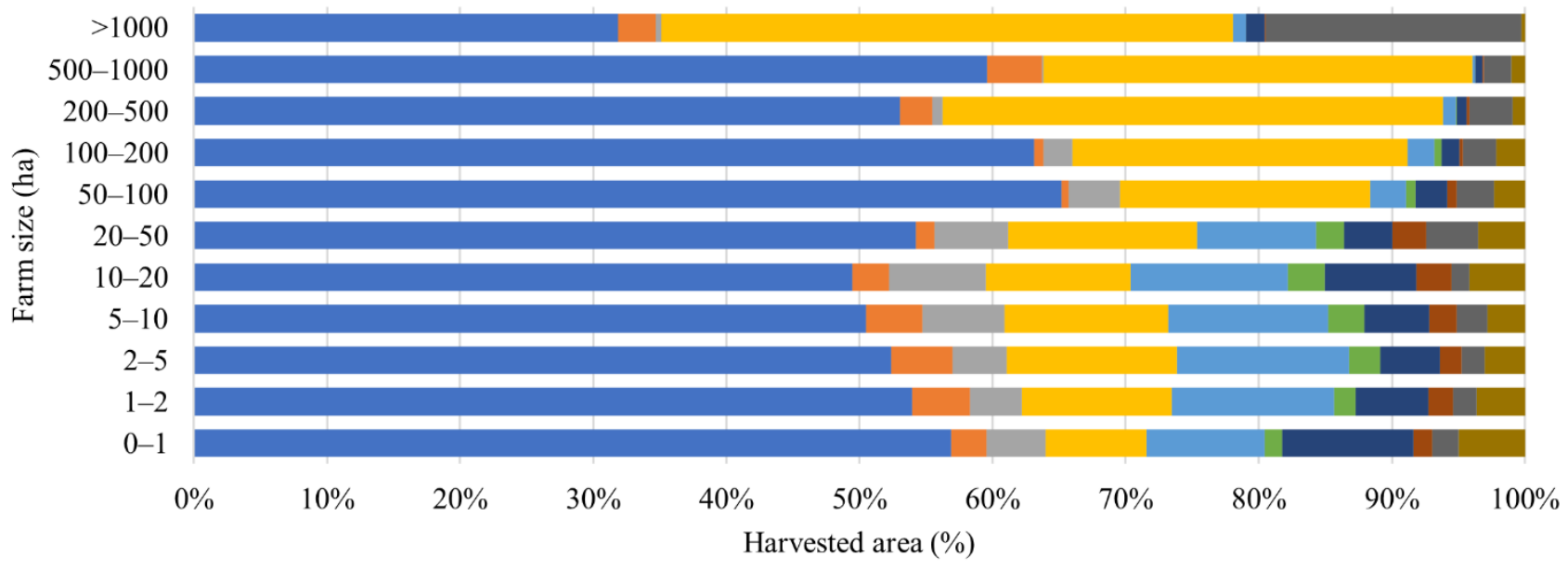

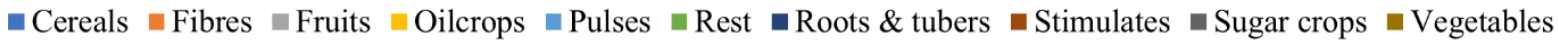

(a)

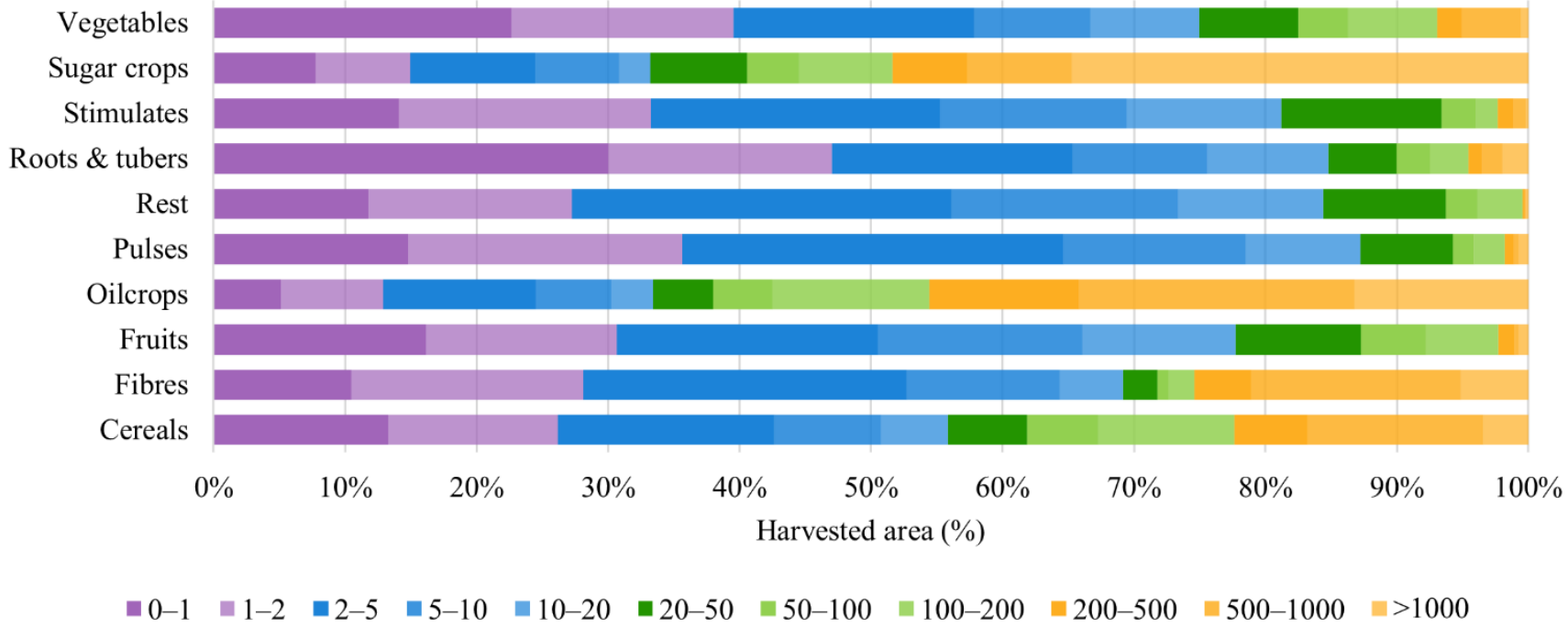

(b)

410 Figure A2. Harvested area of crop groups within each farm size (a) and harvested area of crop groups by farm size (b) according to SPAM based downscaled map. 


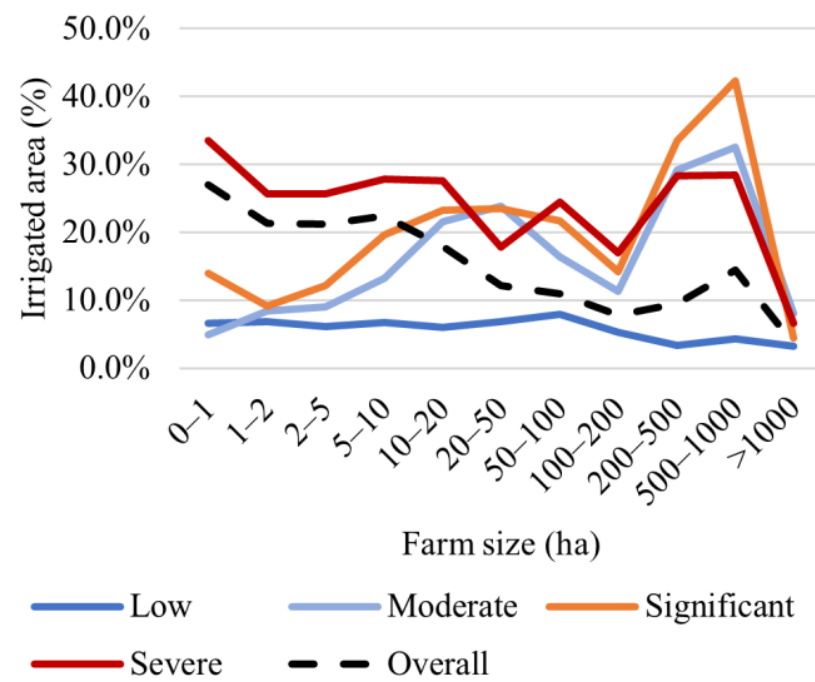

(a)

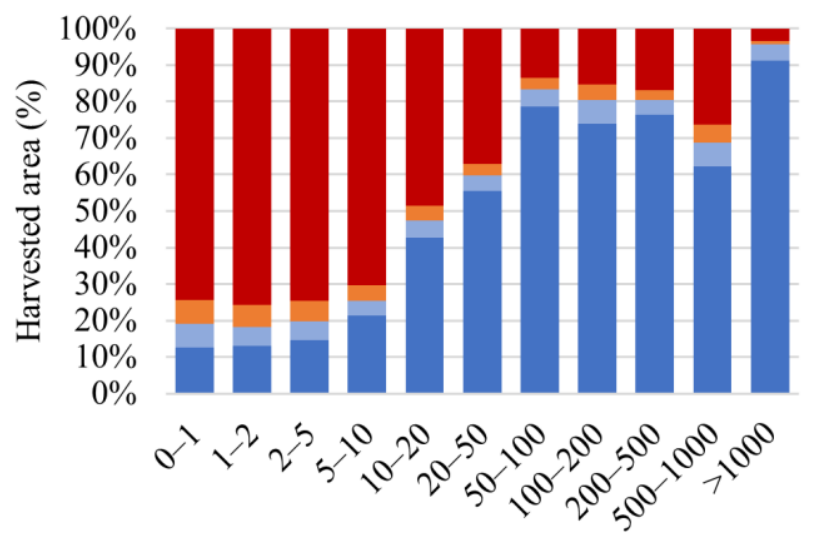

Farm size (ha)

$\square$ Low $\backsim$ Moderate $\square$ Significant $\square$ Severe

(b)

Figure A3. The percentage of the irrigated area by farm size under each water scarcity level (a) and levels of water scarcity within each farm size (b) according to SPAM based downscaled map.

\section{Author contribution}

The concept of this work originated from HS during the discussion with MSK and RJH. The study was then designed and conducted by HS under the supervision of BM and DLG with feedback from MSK and RJH. HS wrote the draft of this manuscript. HS, BM, DLG, MSK, and RJH were involved in the analysis of results and revision of the manuscript.

\section{Competing interests}

420 The authors declare that they have no conflict of interest.

\section{Acknowledgements}

This study is funded in part by the European Research Council (ERC) Advanced Grant 2018 (action number 834716) and the University of Twente. Part of the research was developed in the Young Scientists Summer Program (YSSP) at the International Institute for Applied Systems Analysis, Laxenburg (Austria).

\section{References}

Bosc, P.-M., Berdegué, J., Goïta, M., van der Ploeg, J. D., Sekine, K., and Zhang, L.: Investing in smallholder agriculture for food security, HLPE, 2013. 
https://doi.org/10.5194/essd-2022-72

Preprint. Discussion started: 7 March 2022

(c) Author(s) 2022. CC BY 4.0 License.

Descals, A., Wich, S., Meijaard, E., Gaveau, D., Peedell, S., and Szantoi, Z.: High-resolution global map of smallholder and industrial closed-canopy oil palm plantations, Earth System Science Data, 2020.

430 EUROSTAT: EUROSTAT, Agriculture, forestry and fisheries, Africulture, Farm structure, 2021.

FAO: FAOSTAT, 2019.

FAO: World Programme for the Census of Agriculture, 2020.

FAO: RuLIS - Rural Livelihoods Information System, 2021.

Fischer, G., Nachtergaele, F. O., van Velthuizen, H., Chiozza, F., Francheschini, G., Henry, M., Muchoney, D., and Tramberend, S.: Global

435 Agro-ecological Zones (GAEZ v4)-Model Documentation, FAO Rome, Italy, 2021.

Fritz, S., See, L., McCallum, I., You, L., Bun, A., Moltchanova, E., Duerauer, M., Albrecht, F., Schill, C., Perger, C., Havlik, P., Mosnier, A., Thornton, P., Wood-Sichra, U., Herrero, M., Becker-Reshef, I., Justice, C., Hansen, M., Gong, P., Abdel Aziz, S., Cipriani, A., Cumani, R., Cecchi, G., Conchedda, G., Ferreira, S., Gomez, A., Haffani, M., Kayitakire, F., Malanding, J., Mueller, R., Newby, T., Nonguierma, A., Olusegun, A., Ortner, S., Rajak, D. R., Rocha, J., Schepaschenko, D., Schepaschenko, M., Terekhov, A., Tiangwa, A., Vancutsem, C.,

440 Vintrou, E., Wenbin, W., van der Velde, M., Dunwoody, A., Kraxner, F., and Obersteiner, M.: Mapping global cropland and field size, Glob Chang Biol, 21, 1980-1992, 10.1111/gcb.12838, 2015.

Gollin, D.: Farm size and productivity: Lessons from recent literature, 1-35, 2019.

Grafton, R. Q., Williams, J., Perry, C. J., Molle, F., Ringler, C., Steduto, P., Udall, B., Wheeler, S. A., Wang, Y., Garrick, D., and Allen, R. G.: The paradox of irrigation efficiency, Science, 361, 748-750, 2018.

445 Gurobi Optimization, L.: Gurobi Optimizer Reference Manual, 2021.

Herrero, M., Thornton, P. K., Power, B., Bogard, J. R., Remans, R., Fritz, S., Gerber, J. S., Nelson, G., See, L., Waha, K., Watson, R. A., West, P. C., Samberg, L. H., van de Steeg, J., Stephenson, E., van Wijk, M., and Havlík, P.: Farming and the geography of nutrient production for human use: a transdisciplinary analysis, The Lancet Planetary Health, 1, e33-e42, 10.1016/s2542-5196(17)30007-4, 2017.

Hoekstra, A. Y., Mekonnen, M. M., Chapagain, A. K., Mathews, R. E., and Richter, B. D.: Global monthly water scarcity: blue water

450 footprints versus blue water availability, PLoS One, 7, e32688, 10.1371/journal.pone.0032688, 2012.

Kim, K.-H., Doi, Y., Ramankutty, N., and Iizumi, T.: A review of global gridded cropping system data products, Environmental Research Letters, 16, 10.1088/1748-9326/ac20f4, 2021.

Latham, J., Cumani, R., Rosati, I., and Bloise, M.: Global land cover share (GLC-SHARE) database beta-release version 1.0-2014, FAO, Rome, Italy, 2014.

455 Lesiv, M., Laso Bayas, J. C., See, L., Duerauer, M., Dahlia, D., Durando, N., Hazarika, R., Kumar Sahariah, P., Vakolyuk, M., Blyshchyk, V., Bilous, A., Perez-Hoyos, A., Gengler, S., Prestele, R., Bilous, S., Akhtar, I. U. H., Singha, K., Choudhury, S. B., Chetri, T., Malek, Z., Bungnamei, K., Saikia, A., Sahariah, D., Narzary, W., Danylo, O., Sturn, T., Karner, M., McCallum, I., Schepaschenko, D., Moltchanova, E., Fraisl, D., Moorthy, I., and Fritz, S.: Estimating the global distribution of field size using crowdsourcing, Glob Chang Biol, 25, 174-186, $10.1111 /$ gcb.14492, 2019.

460 Lowder, S. K., Sánchez, M. V., and Bertini, R.: Which farms feed the world and has farmland become more concentrated?, World Development, 142, 10.1016/j.worlddev.2021.105455, 2021.

Lowder, S. K., Skoet, J., and Raney, T.: The Number, Size, and Distribution of Farms, Smallholder Farms, and Family Farms Worldwide, World Development, 87, 16-29, 10.1016/j.worlddev.2015.10.041, 2016.

Lu, M., Wu, W., You, L., See, L., Fritz, S., Yu, Q., Wei, Y., Chen, D., Yang, P., and Xue, B.: A cultivated planet in 2010 - Part 1: The 465 global synergy cropland map, Earth System Science Data, 12, 1913-1928, 10.5194/essd-12-1913-2020, 2020.

Mehrabi, Z., McDowell, M. J., Ricciardi, V., Levers, C., Martinez, J. D., Mehrabi, N., Wittman, H., Ramankutty, N., and Jarvis, A.: The global divide in data-driven farming, Nature Sustainability, 4, 154-160, 10.1038/s41893-020-00631-0, 2020.

Meyfroidt, P.: Mapping farm size globally: benchmarking the smallholders debate, Environmental Research Letters, 12, 10.1088/17489326/aa5ef6, 2017.

470 Monfreda, C., Ramankutty, N., and Foley, J. A.: Farming the planet: 2. Geographic distribution of crop areas, yields, physiological types, and net primary production in the year 2000, Global Biogeochemical Cycles, 22, n/a-n/a, 10.1029/2007gb002947, 2008.

Noack, F., Larsen, A., Kamp, J., and Levers, C.: A bird's eye view of farm size and biodiversity: The ecological legacy of the iron curtain, American Journal of Agricultural Economics, 10.1111/ajae.12274, 2021.

Ray, D. K., Mueller, N. D., West, P. C., and Foley, J. A.: Yield trends are insufficient to double global crop production by 2050, PloS one,

475 8, e66428, 2013.

Ren, C., Liu, S., van Grinsven, H., Reis, S., Jin, S., Liu, H., and Gu, B.: The impact of farm size on agricultural sustainability, Journal of Cleaner Production, 220, 357-367, 10.1016/j.jclepro.2019.02.151, 2019.

Ricciardi, V., Mehrabi, Z., Wittman, H., James, D., and Ramankutty, N.: Higher yields and more biodiversity on smaller farms, Nature Sustainability, 4, 651-657, 10.1038/s41893-021-00699-2, 2021.

480 Ricciardi, V., Ramankutty, N., Mehrabi, Z., Jarvis, L., and Chookolingo, B.: An open-access dataset of crop production by farm size from agricultural censuses and surveys, Data Brief, 19, 1970-1988, 10.1016/j.dib.2018.06.057, 2018a.

Ricciardi, V., Ramankutty, N., Mehrabi, Z., Jarvis, L., and Chookolingo, B.: How much of the world's food do smallholders produce?, Global Food Security, 17, 64-72, 2018 b. 
https://doi.org/10.5194/essd-2022-72

Preprint. Discussion started: 7 March 2022

(c) Author(s) 2022. CC BY 4.0 License.

(c) (1)

Ricciardi, V., Wane, A., Sidhu, B. S., Godde, C., Solomon, D., McCullough, E., Diekmann, F., Porciello, J., Jain, M., and Randall, N.: A 485 scoping review of research funding for small-scale farmers in water scarce regions, Nature Sustainability, 3, 836-844, 2020.

Riesgo, L., Louhichi, K., Gomez y Paloma, S., Hazell, P., Ricker-Gilbert, J., Wiggins, S., Sahn, D. E., and Mishra, A. K.: Food and nutrition security and role of smallholder farms: challenges and opportunities, Institute for Prospective Technological Studies; Information for Meeting Africa's Agricultural Transformation and Food Security Goals (IMAAFS),

Rudra, A.: Farm size and yield per acre, Economic Political Weekly, 1041-1044, 1968.

490 Samberg, L. H., Gerber, J. S., Ramankutty, N., Herrero, M., and West, P. C.: Subnational distribution of average farm size and smallholder contributions to global food production, Environmental Research Letters, 11, 10.1088/1748-9326/11/12/124010, 2016.

Savastano, S. and Scandizzo, P.: Farm Size and Productivity: A "Direct-Inverse-Direct" Relationship, 2017.

Su, H., Willaarts, B., Luna Gonzalez, D., S. Krol, M., and J. Hogeboom, R.: Gridded 5 arcmin farm-size specific and crop specific harvested area for 56 countries, https://doi.org/10.5281/zenodo.5747616, 2022.

495 Yu, Q., You, L., Wood-Sichra, U., Ru, Y., Joglekar, A. K. B., Fritz, S., Xiong, W., Lu, M., Wu, W., and Yang, P.: A cultivated planet in 2010 - Part 2: The global gridded agricultural-production maps, Earth System Science Data, 12, 3545-3572, 10.5194/essd-12-3545-2020, 2020. 